\title{
Micrococcus lactis sp. nov., isolated from dairy industry waste
}

\author{
Chittpurna, Pradip K. Singh, Dipti Verma, Anil Kumar Pinnaka, \\ Shanmugam Mayilraj and Suresh Korpole
}

\author{
Correspondence \\ Suresh Korpole \\ suresh@imtech.res.in
}

\author{
Microbial Type Culture Collection and Gene bank, Institute of Microbial Technology, Sector 39A, \\ Chandigarh - 160 036, India
}

The genus Micrococcus was first described by Cohn (1872) and was subsequently emended repeatedly (Stackebrandt et al., 1995; Wieser et al., 2002). It comprises Gram-positive, non-spore-forming, aerobic, non-motile cocci. All species of the genus with validly published names were isolated from different environments, such as a wall painting, air, activated sludge (Wieser et al., 2002; Liu et al., 2007), roots of plants (Chen et al., 2009; Zhao et al., 2009) and soil (Liu et al., 2000; Zhang et al., 2010). The genus Micrococcus is phylogenetically closely related to other genera of the family Micrococcaceae and exhibits similarity in many properties, including chemotaxonomic markers (Stackebrandt et al., 1995). In the present study we isolated a strain designated DW $152^{\mathrm{T}}$ from an industrial effluent plant of the dairy industry located at Hyderabad, India. The polyphasic characterization of this strain indicated that it represents a novel species of the genus Micrococcus.

Strain $\mathrm{DW} 152^{\mathrm{T}}$ was isolated from liquid samples obtained from a dairy waste treatment plant. Upon transfer of the

Abbreviations: DPG, diphosphatidylglycerol; PG, phosphatidylglycerol; $\mathrm{PI}$, phosphatidylinositol; $\mathrm{PC}$, phosphatidylcholine.

The GenBank/EMBL/DDBJ accession number for the 16S rRNA gene sequence of strain DW152 ${ }^{\top}$ is FN673681.

Three supplementary figures are available with the online version of this paper. samples to the laboratory, they were serially diluted and plated onto nutrient agar (Hi-Media). After incubation at $30{ }^{\circ} \mathrm{C}$, a yellow-pigmented colony was isolated, subcultured and preserved at $-70{ }^{\circ} \mathrm{C}$ for further studies. Morphological characteristics like cell shape and size were observed under a phase-contrast microscope (Axiophot; Zeiss). An active culture was assigned for Gram staining using the Hi-Media kit according to the instructions of the manufacturer. Physiological tests such as growth at different temperatures and $\mathrm{pH}$ were determined using nutrient broth (Hi-Media), measuring the growth as OD at $660 \mathrm{~nm}$ by using a spectrophotometer (Lambda 25, Perkin Elmer). To determine salt tolerance, nutrient agar without $\mathrm{NaCl}$ was supplemented with different concentrations of $\mathrm{NaCl}$. Assimilation of different substrates by strain $\mathrm{DW} 152^{\mathrm{T}}$ was determined using the Biolog Microlog system (release 4.2) according to the manufacturer's instructions except that the strain was grown on tryptone soya agar (TSA; Hi-Media) medium instead of Biolog universal agar. Biochemical tests for catalase and oxidase were determined as described by Cowan \& Steel (1965). Hydrolysis of aesculin, indole, VogesProskauer and methyl red tests, $\mathrm{H}_{2} \mathrm{~S}$ production and nitrate reduction were performed as described by Lanyi (1987). Utilization of various carbon compounds and casein, gelatin, starch and Tween hydrolysis were determined as described by Smibert \& Krieg (1994). Further ability to produce acid from different sugars was checked on medium containing ( $\mathrm{g}$ per 
$100 \mathrm{ml}$ ): $\mathrm{KCl}, 0.01$; yeast extract, $0.01 ; \mathrm{KH}_{2} \mathrm{PO}_{4}, 0.025$; $\mathrm{MgSO}_{4} .7 \mathrm{H}_{2} \mathrm{O}, 0.025 ;\left(\mathrm{NH}_{4}\right)_{2} \mathrm{SO}_{4}, 0.2$; Bromocresol Purple (BCP, pH indicator), 0.02 ; and supplemented with $1.0 \%$ of each filter-sterilized carbon compound.

Microscopic studies revealed that cells of strain DW $152^{\mathrm{T}}$ were Gram-positive and non-spore-forming cocci, present in pairs, and their appearance as diplococci indicated that cell division was by binary fission (Supplementary Fig. S1 available in IJSEM Online). They could grow at $10{ }^{\circ} \mathrm{C}$ but not at $42{ }^{\circ} \mathrm{C}$ and growth was observed between $\mathrm{pH} 4.5$ and 9.0. Strain DW $152^{\mathrm{T}}$ could not grow at high salinity in comparison to other strains that grew with $10 \% \mathrm{NaCl}$. The casein hydrolysis activity of strain DW $152^{\mathrm{T}}$ may allow it to utilize casein present in dairy waste. Other properties of strain DW $152^{\mathrm{T}}$ along with those of closely related species are given in Table 1 .

Total cellular fatty acid methyl esters were extracted from culture grown on nutrient agar at $30{ }^{\circ} \mathrm{C}$ for $48 \mathrm{~h}$ (Sato \& Murata, 1988) and analysed by using the Microbial Identification System (MIDI). The analysis was performed according to the instructions of MIDI (Sasser, 1990). Menaquinones and polar lipids were extracted from freezedried cells and analysed as described by Minnikin et al. (1984). Peptidoglycan was extracted according to Komagata \& Suzuki (1987) and amino acids were identified by comparison with standards. The type of peptidoglycan was identified according to the classification system described by Schleifer \& Kandler (1972). The G + C content of genomic DNA was estimated spectrophotometrically (Lambda 25; Perkin Elmer) as described by Mandel \& Marmur (1968).

The total cellular fatty acid profile was obtained for strain DW $152^{\mathrm{T}}$ along with other closely related strains after growth under identical conditions and the compositions are compared in Table 2. The FAME analysis indicated that fatty acid ai- $\mathrm{C}_{15: 0}$ was the common major fatty acid amongst all species of the genus Micrococcus. Other fatty acids observed in significant quantities for strain $\mathrm{DW} 152^{\mathrm{T}}$ were $\mathrm{i}-\mathrm{C}_{16: 1} \mathrm{H}$ and ai- $\mathrm{C}_{17: 1} \omega 9 \mathrm{c}$, representing 8.73 and $6.92 \%$ of the total, respectively. Interestingly, these were found to be absent in other close relatives like M. terreus NBRC $104258^{\mathrm{T}}$ and M. lylae DSM $20315^{\mathrm{T}}$. However, saturated fatty acids were predominant in all strains. Respiratory isoprenoid quinone analysis indicated the presence of MK- $8\left(\mathrm{H}_{2}\right)$ as major quinone and MK-7 $\left(\mathrm{H}_{2}\right)$, MK-9 $\left(\mathrm{H}_{2}\right)$ and MK-7 as minor menaquinones. Cell-wall peptidoglycan analysis revealed that strain $\mathrm{DW} 152^{\mathrm{T}}$ contained the amino acids lysine, aspartic acid, alanine and glycine. The presence of $\mathrm{L}$ lysine as the diagnostic amino acid classified the peptidoglycan as type $\mathrm{A} 4 \alpha$, which is characteristic of the genus Micrococcus. Total polar lipid analysis of strain DW $152^{\mathrm{T}}$ indicated that it had diphosphatidylglycerol (DPG), phosphatidylglycerol (PG), phosphatidylinositol (PI), phosphatidylcholine $(\mathrm{PC})$, one unknown phospholipid and two unknown glycolipids (Supplementary Fig. S2). Strain DW $152^{\mathrm{T}}$ differed in biochemical and chemotaxonomic properties from closely related species of the genus
Micrococcus (Table 1). The total genomic DNA G+C content of strain $\mathrm{DW} 152^{\mathrm{T}}$ was $68.0 \mathrm{~mol} \%$, as estimated by the $T_{\mathrm{m}}$ method, which is within the limits of the DNA G +C content reported for other species of the genus.

PCR amplification of the 16S rRNA gene was done using primers 8 -27f ( $5^{\prime}$-AGAGTTTGATCCTGGCTCAG- $\left.3^{\prime}\right)$ and 1492r (5'-TACGGYTACCTTGTTACGACTT-3') as described by Pandey et al. (2002). The amplified PCR product was purified and sequenced as described by Suresh et al. (2006). The almost complete sequence of the $16 \mathrm{~S}$ rRNA gene (1429 bp continuous stretch) was obtained and used for the initial BLAST search. Closely related sequences were retrieved from the EMBL database. Sequence alignment was done using CLUSTAL X (Thompson et al., 1997) and results obtained were edited manually. Phylogenetic trees were reconstructed using the maximum-likelihood algorithm using the PhyML program (Guindon \& Gascuel, 2003). The stability among the groupings of the phylogenetic tree was assessed by taking 100 replicates. Actinomyces bovis CCUG $31996^{\mathrm{T}}$ was used as an outgroup.

BLAST analysis of the 16S rRNA gene sequence (1429 bp) using the EZ Taxon server indicated that strain DW152 exhibited $97.03 \%$ similarity with $M$. terreus $\mathrm{V} 3 \mathrm{M1}^{\mathrm{T}}$. Further, pairwise comparative analysis of the sequence indicated that it had low similarity with the type strains of different species belonging to the genera Micrococcus and Arthrobacter. Both of these genera belong to the family Micrococcaceae of the class Actinobacteria (Stackebrandt et al., 1997) and it was observed that different families belonging to this class have high similarity in the primary structure of their $16 \mathrm{~S}$ rRNA genes. However, strain DW152 ${ }^{\mathrm{T}}$ was affiliated to the genus Micrococcus due to the absence of a rod-coccus cycle, presence of chemotaxonomic markers similar to those found in members of the genus Micrococcus, and high similarity of the 16S rRNA gene sequence with that of $M$. terreus NBRC $104258^{\mathrm{T}}$. In particular, $\mathrm{MK}-8\left(\mathrm{H}_{2}\right)$ as major menaquinone, the polar lipids DPG, PG, PI and unknown glycolipids, ai- $\mathrm{C}_{15: 0}$ and $\mathrm{i}-\mathrm{C}_{15: 0}$ as major fatty acids and L-lysine as diagnostic amino acid were observed for strain DW152 ${ }^{\mathrm{T}}$, characteristic of the genus Micrococcus. DNA-DNA hybridization results for strain DW $152^{\mathrm{T}}$ with $M$. terreus NBRC $104258^{\mathrm{T}}$ revealed a mean value of $42.3 \%$ relatedness. According to accepted criteria, more than 3\% difference in 16S rRNA gene sequence represents similarity of less than $70 \%$ at the whole-genome level (Stackebrandt \& Goebel, 1994) and thus it is assumed that whole-genome DNA similarity amongst other species would be quite low. Further, phylogenetic analysis of the 16S rRNA gene sequence assigned strain DW152 ${ }^{\mathrm{T}}$ to the genus Micrococcus as it formed a distinct clade in the maximum-likelihood phylogenetic tree with a bootstrap value of $90 \%$ (Fig. 1). An additional maximum-likelihood phylogenetic tree reconstructed for strain DW $152^{\mathrm{T}}$ along with species of closely related genera belonging to family Micrococcaceae also revealed that strain $\mathrm{DW} 152^{\mathrm{T}}$ formed a distinct clade (Supplementary Fig. S3). The differences in phenotypic properties, low DNA similarity and phylogenetic analysis readily differentiated strain $\mathrm{DW} 152^{\mathrm{T}}$ from the nearest 
Table 1. Physiological and biochemical characteristics of strain $D W 152^{\top}$ and related species of the genus Micrococcus

Strains: 1, DW152 $;$; 2, M. terreus NBRC $104258^{\mathrm{T}} ; 3$, Micrococcus lylae DSM $20315^{\mathrm{T}}$; 4, Micrococcus luteus MTCC106 ${ }^{\mathrm{T}}$; 5 , Micrococcus yunnanensis YIM $65004^{\mathrm{T}} ; 6$, Micrococcus antarcticus AS $1.2372^{\mathrm{T}} ; 7$, Micrococcus flavus LW ${ }^{\mathrm{T}}$. All strains are non-motile and catalase-positive. + , Positive; -, negative; NR, not reported; w, weakly positive; UL1, unknown phospholipid; GL1-3, unknown glycolipids.

\begin{tabular}{|c|c|c|c|c|c|c|c|}
\hline Characteristic & 1 & 2 & 3 & 4 & $5^{a_{\star}}$ & $6^{b, c}$ & $7^{c, d}$ \\
\hline \multicolumn{8}{|l|}{ Growth at/with: } \\
\hline $10{ }^{\circ} \mathrm{C}$ & + & - & - & - & + & + & - \\
\hline $42{ }^{\circ} \mathrm{C}$ & - & - & + & + & + & NR & - \\
\hline $4 \% \mathrm{NaCl}$ & + & + & + & + & NR & NR & NR \\
\hline $6 \% \mathrm{NaCl}$ & - & - & + & + & + & + & - \\
\hline $\mathrm{pH} 4.5$ & + & - & + & - & - & $\mathrm{NR}$ & NR \\
\hline Simmons citrate agar & - & + & + & - & NR & + & - \\
\hline Nitrate reduction & + & - & + & + & - & + & - \\
\hline $\begin{array}{l}\text { Voges-Proskauer } \\
\text { reaction }\end{array}$ & - & - & - & - & - & + & - \\
\hline Indole & - & - & - & - & - & + & - \\
\hline \multicolumn{8}{|l|}{ Hydrolysis of: } \\
\hline Tween 20 & - & + & $-\dagger$ & $-\dagger$ & NR & + & - \\
\hline Tween 80 & - & + & $-\dagger$ & - & + & + & - \\
\hline Casein & + & $+\S$ & - & + & $\mathrm{NR}$ & NR & NR \\
\hline Starch & - & - & - & - & - & + & + \\
\hline Urea & + & $+\S$ & $+\dagger$ & $-\dagger$ & - & - & - \\
\hline \multicolumn{8}{|l|}{ Acid production from: } \\
\hline Glucose & - & - & - & + & $\mathrm{NR}$ & - & - \\
\hline Sucrose & - & + & - & + & $\mathrm{NR}$ & - & - \\
\hline \multicolumn{8}{|l|}{ Assimilation of: } \\
\hline $\begin{array}{l}N \text {-Acetyl-D- } \\
\text { glucosamine }\end{array}$ & - & - & - & $+\dagger$ & NR & $\mathrm{NR}$ & NR \\
\hline L-Arabinose & - & + & - & - & NR & NR & NR \\
\hline D-Glucose & - & + & + & + & NR & - & - \\
\hline Glycerol & + & - & + & + & NR & $\mathrm{NR}$ & NR \\
\hline Trehalose & - & - & $+\ddagger$ & + & + & - & + \\
\hline $\begin{array}{l}\beta \text {-Hydroxybutyric } \\
\text { acid }\end{array}$ & + & + & + & - & NR & $\mathrm{NR}$ & NR \\
\hline$\alpha$-Ketoglutaric acid & - & - & + & $\mathrm{w}$ & NR & - & - \\
\hline L-Lactic acid & - & - & + & + & NR & NR & - \\
\hline L-Malic acid & + & $-\S$ & $+\ddagger$ & - & NR & + & - \\
\hline Maltose & + & + & + & + & NR & + & - \\
\hline $\begin{array}{l}N \text {-Acetyl-L-glutamic } \\
\text { acid }\end{array}$ & - & - & + & - & NR & $\mathrm{NR}$ & NR \\
\hline L-Glutamic acid & + & + & - & - & NR & NR & - \\
\hline $2^{\prime}$-Deoxyadenosine & - & + & + & - & NR & NR & NR \\
\hline Thymidine & - & - & + & - & NR & NR & NR \\
\hline Menaquinones & $\begin{array}{c}\text { MK-8(H2), MK- } \\
\text { 7(H2), MK-9(H2), } \\
\text { MK-7 }\end{array}$ & $\begin{array}{c}\text { MK-7, MK-7(H2), } \\
\text { MK-8, MK- } \\
8(\mathrm{H} 2)\end{array}$ & MK-8(H2) & $\begin{array}{c}\text { MK-8, } \\
\text { MK-8(H2) }\end{array}$ & $\begin{array}{r}\mathrm{MK}-8(\mathrm{H} 2), \\
\mathrm{MK}-7(\mathrm{H} 2)\end{array}$ & $\begin{array}{c}\text { MK-8, MK- } \\
8(\mathrm{H} 2)\end{array}$ & $\begin{array}{r}\text { MK-8(H2), } \\
\text { MK-7(H2) }\end{array}$ \\
\hline Polar lipids & $\begin{array}{l}\text { DPG, PG, PC, PI, } \\
\text { UPL1, GL1, GL2 }\end{array}$ & $\begin{array}{c}\text { DPG, PG, PC, PI, } \\
\text { UPL1§, GL1, } \\
\text { GL2, GL3 }\end{array}$ & $\begin{array}{r}\text { DPG, PG, PI, } \\
\text { UPL1, UPL2 }\end{array}$ & $\begin{array}{l}\text { DPG, PG, PI, } \\
\text { UPL1, UPL2, } \\
\text { GL1, GL2 }\end{array}$ & $\begin{array}{c}\text { DPG, PG, PI, } \\
\text { UPL1 }\end{array}$ & NR & NR \\
\hline $\begin{array}{l}\text { DNA G }+ \text { C content } \\
(\mathrm{mol} \%)\end{array}$ & 68.0 & 69.0 & 70.0 & 67.2 & 71.7 & 66.4 & 71.4 \\
\hline
\end{tabular}

${ }^{\star}$ Data from: $a$, Zhao et al. (2009); b, Liu et al. (2000); c, Zhang et al. (2010); d, Liu et al. (2007).

$\dagger$ Different results obtained by Wieser et al. (2002) using similar methods.

¥Different results obtained by Wieser et al. (2002) who used different methods.

$\S$ Different results obtained by Zhang et al. (2010) who used different methods. 
Table 2. Cellular fatty acid compositions of strain DW $152^{\top}$ and the type strains of species of the genus Micrococcus

Strains: 1 , DW $152^{\mathrm{T}} ; 2$, M. terreus NBRC $104258^{\mathrm{T}} ; 3$, M. lylae DSM $20315^{\mathrm{T}}$; 4, M. luteus $\mathrm{MTCC}^{\mathrm{T}} \mathrm{6}^{\mathrm{T}}$; 5, M. yunnanensis YIM $65004^{\mathrm{T}}$; 6, M. antarcticus AS $1.2372^{\mathrm{T}} ; 7$, M. flavus $\mathrm{LW} 4^{\mathrm{T}}$. Values were obtained in this study unless indicated and are expressed as percentages of total fatty acids; all strains were grown on nutrient agar at $30{ }^{\circ} \mathrm{C}$ for $48 \mathrm{~h}$. -, Absent.

\begin{tabular}{|c|c|c|c|c|c|c|c|}
\hline Fatty acid & 1 & 2 & 3 & 4 & $5^{\star}$ & $6^{*}$ & $7^{\star}$ \\
\hline $\mathrm{i}-\mathrm{C}_{13: 0}$ & - & - & 1.33 & - & - & 0.06 & 3.98 \\
\hline ai $-C_{13: 0}$ & - & - & - & 0.86 & - & 0.09 & 2.78 \\
\hline $\mathrm{C}_{14: 0}$ & 1.00 & - & 0.72 & - & - & 0.63 & 0.78 \\
\hline $\mathrm{i}-\mathrm{C}_{14: 0}$ & 2.45 & 3.14 & 1.51 & 1.30 & 7.41 & 6.19 & 3.98 \\
\hline $\mathrm{i}-\mathrm{C}_{15: 0}$ & 7.25 & 11.05 & 40.11 & 9.95 & 13.04 & 12.34 & 23.35 \\
\hline ai $-C_{15: 0}$ & 68.06 & 72.23 & 48.04 & 78.38 & 61.98 & 63.66 & 41.92 \\
\hline $\mathrm{i}-\mathrm{C}_{16: 1} \mathrm{H}$ & 8.73 & - & - & 2.61 & - & - & 1.13 \\
\hline $\mathrm{i}-\mathrm{C}_{16: 0}$ & 2.86 & 3.55 & 5.26 & 0.82 & 14.25 & 8.29 & 0.34 \\
\hline$C_{16: 0}$ & - & 2.20 & 0.86 & - & - & 1.00 & - \\
\hline ai- $\mathrm{C}_{17: 1} \omega 9 c$ & 6.92 & - & - & 2.61 & - & - & 1.27 \\
\hline ai $-C_{17: 0}$ & 0.86 & 1.42 & 2.16 & 1.03 & 3.32 & 4.17 & - \\
\hline $\begin{array}{l}\text { Summed } \\
\text { feature } 1 \dagger\end{array}$ & 1.77 & - & - & 2.97 & - & - & 17.56 \\
\hline
\end{tabular}

${ }^{\star}$ Data from Zhao et al. (2009).

$\dagger$ Summed feature 1 comprises i- $\mathrm{C}_{15: 1} \mathrm{H}$ and/or $\mathrm{C}_{13: 0} 3 \mathrm{OH}$.

species. Therefore, based on these differences, it is proposed that strain DW152 ${ }^{\mathrm{T}}$ should be recognized as a novel species of the genus Micrococcus, for which the name Micrococcus lactis sp. nov. is proposed.

\section{Description of Micrococcus lactis sp. nov.}

Micrococcus lactis (lac'tis. L. gen. n. lactis from milk, pertaining to the isolation source 'dairy waste').

Cells are cocci with diameter of about $1.0 \mu \mathrm{m}$, stain Grampositive, are non-motile and strictly aerobic. Growth is observed between temperatures of 10 and $40{ }^{\circ} \mathrm{C}$ but not at $42{ }^{\circ} \mathrm{C}$ and between pH 4.5 and 9.5 , the optimum being 7.5. Growth occurs with between 0 and $4 \% \mathrm{NaCl}$. No growth is observed on MacConkey agar. Catalase-positive but oxidase-negative. Exhibits urease activity. Cannot hydrolyse starch, aesculin or Tweens $20,40,60$ or 80 . Positive in the Vitek2 system (bioMérieux) for leucine, alanine, Lproline, tyrosine and L-aspartate arylamidases but negative for ala-phe-pro arylamidase. Positive for $\alpha$-glucosidase but negative for arginine dihydrolase, $\beta$-glucuronidase, $\beta$-galactopyranosidase, $\alpha$-galactosidase, $\beta$-galactosidasemannosidase, phosphatase, and arginine dihydrolase. Exhibits L-lactate alkalinization. Cannot utilize D-ribose, raffinose, cyclodextrin, D-sorbitol, lactose, D-mannitol, salicin, D-mannose, sucrose, trehalose, $\mathrm{N}$-acetyl-D-glucosamine, methyl $\beta$-D-glucopyranoside, D-galactose or pullulan. Sensitive to novobiocin, optochin, polymyxin and bacitracin. Positive for oxidization of the following substrates in Biolog plates: acetate, dextrin, $\alpha$-hydroxybutyric acid, glycerol, inosine, lactate, pyruvic acid, pyruvic acid methyl ester, L-pyroglutamic acid, adenosine, maltose, maltotriose, $\alpha$-ketovaleric acid, D-ribose, sucrose, succinamic acid, succinic acid, succinic acid monomethyl ester, turanose, Tween 40, Tween 80 and glycerol. Cannot oxidize $\alpha$-cyclodextrin, $\beta$-cyclodextrin, inulin, mannan, $N$ acetyl- $\beta$-D-mannosamine, L-arabinose, D-arabitol, arbutin, amygdalin, cellobiose, D-fructose, L-fucose, glycogen, D-galactose, D-galacturonic acid, gentiobiose, D-glucose 6-phosphate, D-gluconic acid, myo-inositol, $\alpha$-lactose, lactulose, D-mannitol, D-mannose, melezitose, melibiose, methyl $\alpha$-D-galactoside, methyl $\beta$-D-galactoside, 3-methylD-glucose, methyl $\alpha$-D-glucoside, methyl $\beta$-D-glucoside, methyl $\alpha$-D-mannoside, palatinose, D-psicose, salicin, sedoheptulosan, D-sorbitol, stachyose, D-tagatose, xylitol, $\gamma$-hydroxybutyric acid, D-lactic acid methyl ester, thymidine 5'-monophosphate, lactamide, D-malic acid, Lalaninamide, D-alanine, L-alanine, glycyl L-glutamic acid, putrescine, adenosine $5^{\prime}$-monophosphate, D-glucose 6-phosphate, uridine 5'-monophosphate, D-fructose 6phosphate or $\alpha$-D-glucose 1-phosphate. The cell wall peptidoglycan of the type strain is type A4 $\alpha$ with L-LysAsp. The polar lipid pattern includes DPG, PG, PI, PC, an unknown phospholipid and two unknown glycolipids. The predominant menaquinone is $\mathrm{MK}-8\left(\mathrm{H}_{2}\right)$. The major cellular fatty acids are ai- $\mathrm{C}_{15: 0}, \mathrm{i}-\mathrm{C}_{16: 1} \mathrm{H}, \mathrm{i}-\mathrm{C}_{15: 0}$ and ai- $\mathrm{C}_{17: 1} \omega 9 \mathrm{c}$. The $\mathrm{G}+\mathrm{C}$ content of the genomic DNA of the type strain is $68.0 \mathrm{~mol} \%$.

The type strain, DW $152^{\mathrm{T}}\left(=\right.$ MTCC $\left.10523^{\mathrm{T}}=\mathrm{DSM} 23694^{\mathrm{T}}\right)$, was isolated from dairy industry waste.

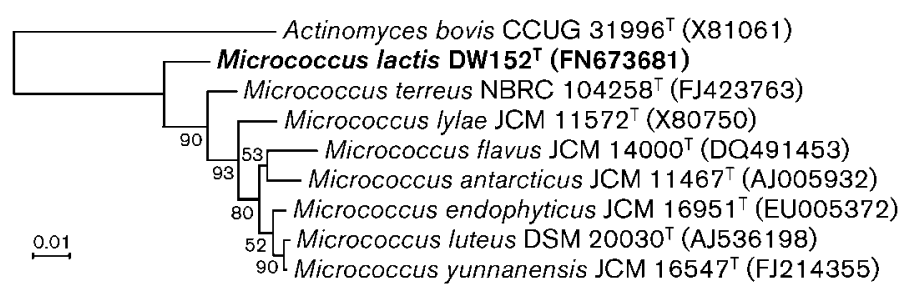

Fig. 1. Maximum-likelihood phylogenetic tree based on 16S rRNA gene sequences showing the relationship of strain DW $152^{\top}$ with members of the genus Micrococcus. Numbers at nodes are bootstrap values $>50 \%$. Actinomyces bovis CCUG $31996^{\top}$ was used as an outgroup. Bar, 0.01 substitutions per nucleotide position. 


\section{Acknowledgements}

We thank the Council of Scientific and Industrial Research (CSIR) and Department of Biotechnology, Government of India for financial assistance. Financial help from CSIR network project (NWP006) is also duly acknowledged. We would like to thank Mr Deepak for his excellent help in sequencing DNA. This is communication number 058/2010 of the Institute of Microbial Technology.

\section{References}

Chen, H.-H., Zhao, G.-Z., Park, D.-J., Zhang, Y.-Q., Xu, L.-H., Lee, J.-C., Kim, C.-J. \& Li, W.-J. (2009). Micrococcus endophyticus sp. nov., isolated from surface-sterilized Aquilaria sinensis roots. Int J Syst Evol Microbiol 59, 1070-1075.

Cohn, F. (1872). Untersuchungen über Bakterien. Beitr Biol Pflanz 1, 127-224 (in German).

Cowan, S. T. \& Steel, K. J. (1965). Manual for the Identification of Medical Bacteria. London: Cambridge University Press.

Guindon, S. \& Gascuel, O. (2003). A simple, fast, and accurate algorithm to estimate large phylogenies by maximum likelihood. Syst Biol 52, 696-704.

Komagata, K. \& Suzuki, K. (1987). Lipid and cell wall analysis in bacterial systematics. Methods Microbiol 19, 161-207.

Lanyi, B. (1987). Classical and rapid identification methods for medically important bacteria. Methods Microbiol 19, 1-67.

Liu, H., Xu, Y., Ma, Y. \& Zhou, P. (2000). Characterization of Micrococcus antarcticus sp. nov., a psychrophilic bacterium from Antarctica. Int J Syst Evol Microbiol 50, 715-719.

Liu, X.-Y., Wang, B.-J., Jiang, C.-Y. \& Liu, S.-J. (2007). Micrococcus flavus sp. nov., isolated from activated sludge in a bioreactor. Int J Syst Evol Microbiol 57, 66-69.

Mandel, M. \& Marmur, J. (1968). Use of ultraviolet absorbancetemperature profile for determining the guanine plus cytosine content of DNA. Methods Enzymol 12B, 195-206.

Minnikin, D. E., O'Donnell, A. G., Goodfellow, M., Alderson, G., Athalye, M., Schaal, K. \& Parlett, J. H. (1984). An integrated procedure for the extraction of bacterial isoprenoid quinones and polar lipids. J Microbiol Methods 2, 233-241.

Pandey, K. K., Mayilraj, S. \& Chakrabarti, T. (2002). Pseudomonas indica sp. nov., a novel butane-utilizing species. Int J Syst Evol Microbiol 52, 1559-1567.
Sasser, M. (1990). Identification of bacteria by gas chromatography of cellular fatty acids. MIDI Technical note 101. Newark, DE: MIDI Inc.

Sato, N. S. \& Murata, N. (1988). Membrane lipids. Methods Enzymol 167, 251-259.

Schleifer, K. H. \& Kandler, O. (1972). Peptidoglycan types of bacterial cell walls and their taxonomic implications. Bacteriol Rev 36, 407477.

Smibert, R. M. \& Krieg, N. R. (1994). Phenotypic characterization. In Methods for General and Molecular Bacteriology, pp. 607-654. Edited by P. Gerhardt. Washington, DC: American Society for Microbiology.

Stackebrandt, E. \& Goebel, B. M. (1994). Taxonomic note: a place for DNA-DNA reassociation and 16S rRNA sequence analysis in the present species definition in bacteriology. Int J Syst Bacteriol 44, 846849.

Stackebrandt, E., Koch, C., Gvozdiak, O. \& Schumann, P. (1995). Taxonomic dissection of the genus Micrococcus: Kocuria gen. nov., Nesterenkonia gen. nov., Kytococcus gen. nov., Dermacoccus gen. nov., and Micrococcus Cohn 1872 gen. emend. Int J Syst Bacteriol 45, 682692.

Stackebrandt, E., Rainey, F. A. \& Ward-Rainey, N. L. (1997). Proposal for a new hierarchic classification system, Actinobacteria classis nov. Int J Syst Bacteriol 47, 479-491.

Suresh, K., Mayilraj, S. \& Chakrabarti, T. (2006). Effluviibacter roseus gen. nov., sp. nov., isolated from muddy water, belonging to the family 'Flexibacteraceae'. Int J Syst Evol Microbiol 56, 17031707.

Thompson, J. D., Gibson, T. J., Plewniak, F., Jeanmougin, F. \& Higgins, D. G. (1997). The CLUSTAL_X windows interface: flexible strategies for multiple sequence alignment aided by quality analysis tools. Nucleic Acids Res 25, 4876-4882.

Wieser, M., Denner, E. B. M., Kämpfer, P., Schumann, P., Tindall, B., Steiner, U., Vybiral, D., Lubitz, W., Maszenan, A. M. \& other authors (2002). Emended descriptions of the genus Micrococcus, Micrococcus luteus (Cohn 1872) and Micrococcus lylae (Kloos et al. 1974). Int J Syst Evol Microbiol 52, 629-637.

Zhang, J.-Y., Liu, X.-Y. \& Liu, S.-J. (2010). Agrococcus terreus sp. nov. and Micrococcus terreus sp. nov., isolated from forest soil. Int J Syst Evol Microbiol 60, 1897-1903.

Zhao, G.-Z., Li, J., Qin, S., Zhang, Y.-O., Zhu, W.-Y., Jiang, C.-L., Xu, L.-H. \& Li, W.-J. (2009). Micrococcus yunnanensis sp. nov., a novel actinobacterium isolated from surface-sterilized Polyspora axillaris roots. Int J Syst Evol Microbiol 59, 2383-2387. 